\title{
ABSENCE OF RATE PARITY AND ITS CONSEQUENCES IN HOTEL INDUSTRY
}

\author{
Naci Polat ${ }^{1}$
}

\begin{abstract}
Rate parity is one of the most important questions of hotel industry in different countries. It is described as a strategy which offers same rate with same conditions for a certain room category in all sales channels at the same time. In this study, positive and negative characteristics of rate parity will be explored. Before this process, marketing instruments and general characteristics of marketing will be underlined. Especially, price policy has an important position in marketing mix. Price strategies such as high price strategy, low price strategy and market price strategies will be examined where price differentiation has a crucial role. Price policy targets are consisted of financial, volume and customer objectives and rate parity can be found within the rate stability under customer objectives. Shortly, rate stability consists of sum of rate unity, rate transparency and rate parity. Here, the absence of rate parity is questioned and described which is the main discussion topics of hotel industry with qualitative methods. As a result, pros and cons of rate parity will be put in order with the findings of this study and recommendations will be made for the hotel sector. Rate parity will be more understandable for young researchers in order to increase their interest about this special topic.
\end{abstract}

Key words: Marketing Instruments, Price strategies, Rate parity, Hotels

\section{INTRODUCTION}

The issue of room pricing over several distribution channels have been discussedfor a long time but it did not become main research topic under the rate parity (Rutherford; O'Fallon 2007). There have been long discussions and legal decisions about rate parity in Europe since online bookings gained important role in the hotel industry. Ever changing environment and decisions makes this study ready for qualitative search. In this study, the position of pricing policy with similiar aspects theoretically will be underlined. After this process, the practical discussions in Europe about rate parity will be introduced and it will be analyzed how rate parity affects hotels and customers. Large companies are mostly active on the web and their size allows them to have technical expertise and financial resources(Rutherford; O'Fallon 2007). Small hotels do not have same advantages and they are mostly unarmed against big companies. It is now possible to understand whether rate parity is a protection wall or barrier for customers and hotel.

\section{GENERAL FEATURES OF MARKETING MIX}

In 1960, E. Jerome McCarthy introduced marketing mix first time with four Ps classifications. It showed companies how they bring their services to the market. According to Kotler, marketing mix is set of controllable variables that the company can use to influence the customer's feedback. Here, pricing policy as the part of marketing mix will be introduced within traditional and new Ps (Kotler; Bowen;Makens 1996).

\footnotetext{
${ }^{1}$ Assist. Professor, Tourism Faculty, University of Pamukkale, Denizli, Turkey / Visiting Researcher at Hasselt University, IMOB, Diepenbeek, Belgium.
} 


\subsection{The traditional 4 P's and new 3 P's}

The four P's can be showed as follows (Freyer, 2004):

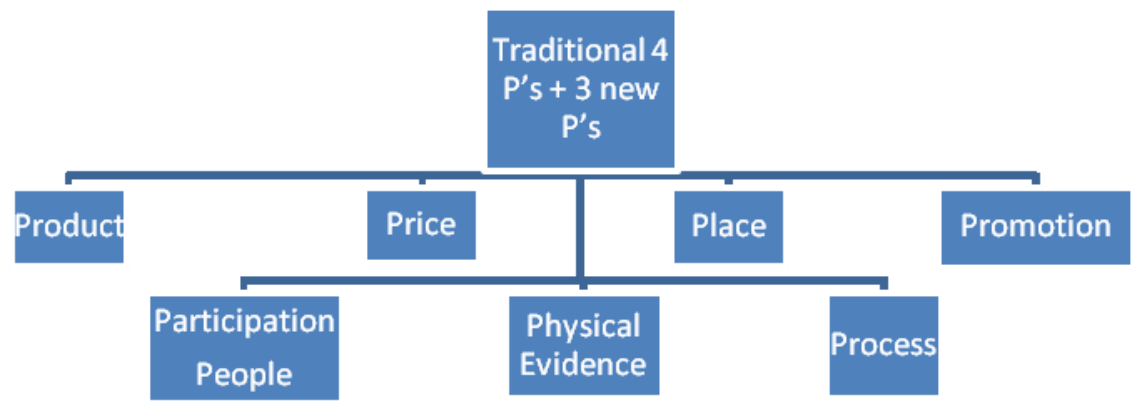

Fig.1. Marketing Mix

\section{PRICING POLICY WITHIN MARKETING MIX}

Pricing policy is finding the price of selling with the help of marketing targets and strategies. Policies are plans for the future direction of the business. Marketing encourages price in order to influence the market (Halloway 2004).

An isolated price policy is not the part of strategic marketing-mix. As marketing was seen as a pricing instrument, this brought only price competition with destroying effects such as price wars. At mature markets, certain price inflexibility can be observed. In strategic marketing, there is a trend of different instruments such as product, distribution and communication policies.

\section{PRICE STRATEGIES}

The most important target of price strategy is to position level of price between certain price levels. More or less, all price policies are aiming to find a place in low, middle and high price segments(Kotler; Bowen; Makens 1996):

- High price strategies

- Low price strategies

- $\quad$ Market price strategies

These basis price strategies have more complex structures than it is assumed. These are mostly related to following structures:

- Cost structures: These build the basis and lower segment of price strategy.

- Price of competitors: This gives possibility for hotels to see at which price level they are finding themselves such as high, middle or low price levels.

- From the perspective of demand: It also allows room to move and gives another perspective instead of competitor's comparison because of internal costperformance structures. 
- The cost-performance relationship: It is important to know what is offered for the paid price.

Now it is possible to put different price strategies together.

\subsection{High Price Policy}

High price policy depends mostly on product quality and exclusivity. Prices are relatively high when it is compared with competitors from the perspective of consumers. It depends on price-performance advantage or creating of customer preferences. There are some competition advantages and monopoly situation which are used as price policy. The most important point is to absorb the monopoly rent. Here are some high price strategies:

\subsubsection{Prestige Pricing}

High price policy is mostly used on a long term as a reward strategy. It tries to build and keep lonely position at this level. Club Med can be mentioned as an important example. Customers are not sensible about the price and they value very much different product and prestige.

\subsubsection{Market-Skimming Pricing}

It is as long as possible to have it after getting temporary and necessary consumer earnings. By the time, price will be stabilizing itself at the market level. On the other hand, it is only possible to use high prices as a price policy for a certain period of time with new products or in attempt to get in new markets with the possibility of competitive advantage.

\subsection{Low Price Strategy}

Low price strategy has lower price level than normal market prices. Low prices help to increase sales volume with high sales and earnings when it's compared with other high level prices. This strategy has its own problems. The success of this strategy is mostly related with price flexibility of demand. If price flexibility is over 1, price cut can bring long term success (Halloway 2004). Here, there is a discussion about the consideration of capacity: More demand can be satisfied with existing or easily created capacities. It is difficult to change to new position if the company is in the position of low-price segment. It could be possible if it is used effective communication (Palma de Mallorca and NUR Touristik)

\subsubsection{Market-penetration Pricing}

If the company tries to enter a new market, there will be a possibility for low prices with the help of high volume of sales and low prices. After successful market entrance, it is possible to increase prices to the level of market. This is explained as penetration policy 


\subsubsection{Product-bundle Pricing}

Different products are combined with low prices. It desensitizes the customer to the price such as in all-inclusive resorts.

\subsubsection{Volume discounts}

There are low price offers for buyers who can buy big numbers.

\subsubsection{Discounts based on time of purchase}

Low price policy can be varied, depending on time or place. Especially, in the high season there is high price policy and in the low season there would be low price policy.

\subsubsection{Discriminatory Pricing}

It is also called as gender based pricing. Ladies Night would be a good example. The product is served with various prices even if it has same costs for men or women.

\subsubsection{Last-Minute Pricing}

Empty capacities are sold with low prices at late dates which are very much used by travel industry.

\subsubsection{Pyschological Pricing}

Prestige, reference prices and prices such as 6.99 or 59.99 are used very effective in order to attract customers.

\subsubsection{Promotional Pricing}

When low prices are seen and used as long term price strategy, there is a promotional pricing strategy. This kind of companies needs cost and production advantage in the long term. These prices can be given with objective approaches or they are seen at low level from the perspective of customers. NUR Touristik is a good example which has low-cost image but its prices are at the same level of its competitors.

\subsection{Market Price Strategy}

Price is not used as an active marketing instrument. A sufficient price structuring is also very important strategic and operative measure. This strategy is offering for all markets with wide middle level and there is very little playground for up and down.

\section{TARGETS OF PRICE POLICY}

It is important to focus on 4 different domestic factors. These factors can focus on finances, capacityand consumers (Halloway 2004). 


\subsection{Price formation with focus on finances}

There are monetary-quantitative targets which are followed by certain price policy such as profit, sales and returns.

\subsection{Price formation with focus on capacity}

-Increasing of market share with competitors, products, service with high quality

-Increasing the use of scale of the hotel rooms

\subsection{Price formation with focus on consumers}

Price formation with focus on costumers can be created with rate stability, rate parity, rate unity.

\subsubsection{Rate stability}

Price stability was not seen as a priority in the hotel industry for a long time (With some budget hotel exceptions). Increasing of internet and other distribution channels raised awareness of many hotels about price stability. Rate stability can be understood as rate unity, rate transparency, rate parity and rate cannibilization.

\subsubsection{Rate parity}

It is described as a strategy which offers same rate with same conditions for a certain room category in all sales channels at the same time. Internet offers customers price transparency and it is an ideal place for price comparison.

\subsubsection{Rate unity}

Customers do not believe that they can find more cheap prices for the same product. Many hotels reach this level of price with the help of internet.

\subsubsection{Rate transparency}

Customer knows best price for the product with the help of internet shopping.

\subsubsection{Rate cannibilazation}

It exists with increasing price transparency without rate parity. Even if customers are ready to pay more, they are mostly attracted to different channels for buying products with lower prices. It causes income loss before the demand arises.

\section{Consequences of Rate Parity Absence in Hotels}

Hotel managers started to use to live with rate parity.Thisis written nearly in every contract between hotels and internet reservation systems. But it was unfair that hotels cannot decide alone about their room prices. Since three years, there is juridical tendencyin Europe that 
the rate parity is prohibited: German Monopoly Agency (Bundeskartellamt) made a decision and prohibited this best-price clause (Taylorwessing 2015). In France, macron law passed in this year. It gives French hotels freedom to decide their own prices on their websites or other booking channels.Turkish Competition Agency has also started investigation about rate parity (booking.com) after the application of Turkish Travel Agencies Association (Türsab 2015).

In the beginning, there was a common sense between hotels and online booking agencies about rate parity. Hotels were ready not to give low prices other than contract partners. This pushed more or less hotels into laziness for being not so effective in sales. Online booking channels became very efficient and powerful with their focused advertisementandbrand development activities. Balance between hotels and online booking channels could not exist anymore. There are positive and negative views about rate parity:

\section{Positive Views:}

- There is a transparent and credible price structures for hotel customers.

- Small and family hotels have their own standart rates and they can control them in every booking portal and channel.

- If there is no price parity, there will be price war within the sector. Internet booking channels must develop their business model and adapt themselves changing conditions. HRS-Manager Ragges mentions that there are two different scenarios (Kwidzinski 2012): Firstly, price parity can become the main listing model of portals or secondly portals can buy big amount of contingents from hotels. Two of these scenarios can ruin small hotels and increase their internal costs.

-Rate parity can stop decrease of brand's price and it gains more importance with alternative bookings in different channels.

\section{Negative Views:}

- Rate parity for different targets restricts the price flexibility of hotel managers.

- To have different number of rates without concrete differentiation between products can confuse customers. They can still have no idea what they get for the money that they pay for (Rutherford 2007).

- German Hotel Association was against the rate parity and insist that this would ruin the competition and the hotel market. Der Hotelverband Deutschland, German Hotel Association (IHA) was against HRS (Hotel Reservation System) at this process. Markus Luthe from IHA says that there will be a real competition between portals and there will be big play ground for hotel managers if there is no rate parity (Kwidzzinski 2012).

- If there is no rate parity, there can be more discounts at hotel web pages or there will be certain upgrades for direct bookings.

- Hotels started to loose the control on their own prices.

\section{Alternatives:}

There are alternatives for bookings beside hotels and booking channels such as metasearch engines. TripAdvisor (Instant booking) made possible to book thousand hotels on its page. Google's hotelfindermakes it possible to make reservation with different channels 
after hotel is found in its web-page. Bookassist is also offering anoher method of solution for hotels. It creats search engine, digital marketing, web design and distribution.

There are alternative online booking portals such as Betandsleep (D) or Priceline.com (USA) as well (AHGZ 2012). At these web pages, customers suggest price of the room and they receive a list of hotels which are ready to accept the price offer. Hotels must not take care of rate parity and they can decrease their prices at that moment without decreasing prices anywhere else. This is an individual process between customer and hotel and the result is not seen anywhere. Hotels can fill their rest capacity and increase their utility. But these bookings cannot be cancelled.

\section{CONCLUSION}

It is mostly clear that pricing is a very complex marketing instrument and it must be made either customer-based or customer-related. When hotels get to be more independent from booking channels-with or without rate parity-, they have to strengthen their direct sales.

Here are some recommendations:

- Hotels must revalue their websites with special content. Most of thetime, hotel's own web pages are not ideal to get interacted if they are compared with distribution channels web-pages. Hotel web-pages must be designed by professionals in order to reach customers emotionally and personally with fewer procedures.

- Customers are thinking whether it is useful to spend time and energy for searching. Hotels can offer better packages such as up-grade, free-in house services or some promotional codes within their web-page.

- There will be some implications because of different prices such as it gives freedom of selection for customers but it can be also contra-productive if customers are tired of looking more reasonable prices. It would be useful to present very strict number of rooms with certain prices. Some of web pages are offering reasonable prices from all channels. But best prices with extra packages are stayed hidden. Rankings are mostly based on pure prices such as without breakfast or other extras. There must be more transparency within mega booking channels (Holidaycheck.de).

- It is also interesting that some lowest prices are introduced by different channels but with high transaction costs with no concrete price strategy. This must be changed in order to have certain standarts.

- Real hotel evaluations, customer's datas must be collected and evaluated by hotel managers and these have to be used for effective marketing with direct e-mailing or social media campaigns.

- Customer loyalty can be created with different loyalityclub and programmes.

- Different customer segments give different reactions for prices. It is sure that hotel willbe evaluated with different perspectives. Price differences between channels must not be at high level. For that,different segments must be defined and these can be priced within a developed system.

- Hotels compete with each other. Online channels have important influence on this. Hotels can stay competitive in the future if they combine booking channels and their own web pages with a strategic pricing. 
- All hotels must develop collaboration for common solutions for rate parity. Hotel chains can loose profits because of rate cuttings and small hotels will not exist because of deadly price competition beside to talk about Airbnb which will be one of the biggest challenges of the hotel industry.

\section{REFERENCES}

Freyer, W. (2004).Tourismus -Marketing ( $4^{\text {th }}$ Ed.). Munich: OldenbourgVerlag.

Halloway, J. C (2004), Marketing for Tourism (4 ${ }^{\text {th }}$ Ed.). New Jersey: Prentice Hall.

Kotler, P.; Bowen, J. T.; Makens C. J. (1996). Marketing for Hospitality and Tourism (4 ${ }^{\text {th }}$ Ed.). New Jersey: Prentice Hall.

Kwidzinski, R. (2012, Mai). HRS-Chef Tobias Ragge verteidigt Ratenparitaet. AHGZ.Retrieved from http://www.ahgz.de/unternehmen/hrs-chef-tobiasragge-verteidigt-ratenparitaet,200012195902.html

Kwidzinski, R. (2012, June). HoteliersstreitenüberRatenparitaet.AHGZ.Retrieved from http://www.ahgz.de/unternehmen/hoteliers-streiten-ueberratenparitaet,200012196608.html

Rutherford, D. G.; O'Fallon M. J. (2007). Hotel Management and Operations (4 ${ }^{\text {th }}$ Ed.). John Wiley \& Sons, Inc.

http://www.ahgz.de/unternehmen/bei-betandsleep-bestimmt-der-gast-denzimmerpreis,200012199791.html (17.10.2012)

http://united-kingdom.taylorwessing.com/newsletter/commercial/newsletter-commercialmaerz-2014/best-price-klauseln-untersagt.html (08.09.2015)

http://www.tursab.org.tr/tr/tursabdan-haberler/genel-duyurular/onemli-duyururekabetkurulu-bookingcom-hakkinda-sorusturma-acilmasina-karar-verdi 13134.html (08.09.2015) 